\title{
Text and Context: Exploring Values of Character in "Al-Qiro'ah Al-Rosyidah" Text
}

\author{
Muassomah Muassomah \\ UIN Maulana Malik Ibrahim Malang \\ Jl. Gajayana 50, Malang, Indonesia \\ muassomah@bsa.uin-malang.ac.id
}

\begin{abstract}
Al-Qiro'ah al-Rosyidah textbook studied by beginner santri (a term for students admitted to study in Islamic boarding schools) in several Islamic boarding schools in Indonesia is due to its simple vocabulary and easy-to-understand word structure character values that are in line with Islamic values. From the textbook, al-Qiro'ah al-Rosyidah, children and adolescents can learn aspects of language and understand the values and norms implied in each text title. This paper aims to explore the character values contained in the textbook alQiro'ah al-Rosyidah. The activities described in the book indicate past activities such as farming, gardening, anchoring, etc. which are different from the present conditions. Therefore, it needs contextualization with value activities in the present. This paper is employing descriptive qualitative research with a literature study approach, namely extracting from a textbook. Data collection was carried out through reading and recording, which were then followed by mapping and classification. Critical discourse analysis techniques are used in analyzing the data in this paper. This paper concludes that the textbook al-Qiro'ah al-Rosyidah contains character values that follow Islamic norms, which are reflected in society's life in the past. These values are in the form of patience, trustworthiness, sincerity, responsibility, help, cooperation, respect for others, etc. This study suggests analyzing the same book as a whole for volumes 1, 2, and 3 so that the values extracted are more diverse according to the varied descriptions of past experiences.
\end{abstract}

Keywords: text al-Qiro'ah al-Rosyidah, character values, character education, text, context.

244 |VOL. 9 NO. 2 DECEMBER 2020 


\begin{abstract}
Abstrak
Buku teks al-Qiro'ah al-Rosyidah yang selama ini dipelajari oleh santri pemula di beberapa pesantren di Indonesia disebabkan kosa kata yang sederhana dan struktur kata yang mudah dipahami, ternyata juga mengandung nilai-nilai karakter yang senada dengan nilai-nilai Islam. Dari buku teks al-Qiro'ah al-Rosyidah anak dan remaja dapat mempelajari aspek-aspek kebahasaan, sekaligus dapat memetik hikmah nilai dan norma yang tersirat di setiap teks. Tulisan ini bertujuan mengeksplorasi nilai-nilai karakter yang termuat dalam dalam buku teks al-Qiro'ah al-Rosyidah. Aktivitas yang digambarkan dalam buku menunjukkan aktivitas masa lalu seperti bertani, berkebun, berlabuh, dan lain-lain yang mana hal ini sudah berbeda dengan kondisi masa kini. Hingga dibutuhkan kontekstualisasi dengan aktivitas nilai di masa sekarang. Tulisan ini berjenis penelitian deskriptif kualitatif dengan pendekatan studi pustaka, yaitu penggalian dari sebuah buku teks. Data dikumpulkan melalui baca dan catat, yang selanjutnya dilakukan pemetaan dan klasifikasi. teknik analisis kritis yang digunakan dalam menganalisa data dalam tulisan ini. Tulisan ini menyimpulkan bahwa buku teks al-Qiro'ah al-Rosyidah telah memuat nilai-nilai karakter yang sesuai dengan norma Islam yang direfleksikan dalam kehidupan masyarakat di masa lalu. Nilai-nilai tersebut berupa sabar, amanah, ikhlas, tanggung jawab, tolong menolong, kerjasama, dan menghargai kepada yang lain. Penelitian ini menyarankan agar dapat melakukan analisis buku yang sama secara keseluruan jilid 1, 2 dan 3 agar nilai yang digali lebih beragam sesuai gambaran pengalaman yang bervariasi pada masa lalu.
\end{abstract}

Kata Kunci: teks al-Qiro'ah al-Rosyidah, Pendidikan karakter, nilai-nilai karakter, teks, konteks

\title{
Introduction
}

Despite the rise of online books (e-books) in the era of the technology industry 4.0, the textbook al-Qiro'ah al-Rasyidah is a still applicable to todays education needs. The book is quite old published in 1953 set. $52^{\text {nd }}$ but it is still relevant to be used as muthala'ah material for students in Islamic boarding schools. This book is used as the core material in several schools based on HERITAGE OF NUSANTARA: INTERNATIONAL JOURNAL OF RELIGIOUS LITERATURE AND HERITAGE $\mid 245$ 
Islam; written in Arabic; but using simple vocabularies to describe daily activities. Apart from that, this book has a teaching content of character values.

In Line in line with this, education today is increasingly responsible for the increasing demoralization of children and adolescents. (Mannuhung, 2019) Even more days, juvenile delinquency increases drastically, especially during a pandemic (Mutohar, 2020), while they are the hope of the nation's successor in the future. (Wijaya, A., Purnomolastu, N., \& Tjahjoanggoro, 2015).

Children and adolescents who fall into the abyss of moral decadence are not only influenced by emotional instability (Yunia, Liyanovitasari, \& Saparwati, 2019) and a lack of attention and supervision from teachers and parents (Harahap, 2017). Children of the current generation are more likely to be individualistic and reluctant to receive advice (Wulandari \& Hodriani, 2019) on the other hand, parents and teachers expect all orders and instructions to be obeyed and carried out without having to ask (Muassomah et al., 2020) This is what makes the existence of al-Qiro'ah al-Rasyidah textbook necessary to explore the values of morality contained in it. It can be considered as alternative character education for children and adolescents and lead them to carry out their activities characterized by noble morals in the textbook al-Qiro'ah alRashidah. Maknun says, for example, that the legacy of the past's text should be explored in term of the Islamic values contained in 246 |VOL. 9 NO. 2 DECEMBER 2020 
it, which is then contextualized in a technological life. (Maknun \& Muzayanah, 2020)

So far, text studies conducted by researchers have three tendencies. First, we want to know the text, (Mujahid, 2016; Syarifah, 2020) such as a study conducted by Febrianti, which explores gender content in citizenship education textbooks. (Febrianti, Abdulkarim, Malihah, \& Fitriasari, 2020) Along with that, Centini manuscripts have reflected Javanese society (Wibawa, 2013). Second, recognizing the teachings in the text of their influence on local culture, (Niampe, 2013; Mashuri, 2017; Christianna, 2018) for example a study of the Suluk text which contains the challenge of Friday prayers and difficulties faced by the community. (Muhsin, 2012) Another manuscript in the form of Serat Sindu Joyo has represented the teachings that Sindu Joyo brought to the Gresik community, which has four pillars, namely: the tradition of commemorating Sindu Joyo's haul, Pencak tiger, macapat, belief in a prohibition of establishing a marriage relationship. (Ardianty, 2014)

The results of Mulyani's study found that the cultural elements in the text of Pomoripun Sarengat, Tarekat, Hakekat, and Makrifat are in the form of the concept of manunggaling kawulo gusti; to achieve this requires a tarekat and makrifat paths. (Mulyani, 2016) Third, exploring the linguistic side of a text. (Anis, Arifuddin, \& Farhah, 2015; Roviin, 2018) This is shown in a study of the concept of symbols in the al-Barzanji 
book, which contains a lot of kinayah and the original meaning of a word when leaning on the word Rasulullah SAW. (Mirnawati, M., 2019) The same study of the Tunjuk Ajar Melayu text found the Malay community's ancestral heritage after the process of understanding the word morphologically, syntactically, and semantically. (Mirnawati, 2019) The Existing studies have not seen much of the text's potential in terms of character values, which should be in line with the notion that every book cannot be separated from messages that should be internalized by every reader.

This paper is to complement the existing study, aims to show that the al-Qiro'ah al-Rosyidah textbook contains good character values and norms according to Islamic teachings. The presentation of the text is in the form of stories of everyday life, which makes it easier to internalize for students (children and adolescents). There are three research questions formulated in this paper: first, how the textbook al-Qiro'ah al-Rosyidah are described? Second, what character values are included in the text al-Qiro'ah al-Rosyidah? Third, how to contextualize the character values contained in the book al-Qiroah al-Rosyidah. The answers to these three questions formulations are the focus of discussion in this paper.

This paper is based on the argument that classic texts, which are sometimes not widely touched and known by the wider community, actually have a monumental message to explore. The textbook al-Qiroah al-Rosyidah is a classic book 248 |VOL. 9 NO. 2 DECEMBER 2020 
that is still used as a reference and as material for Arabic lessons in several Islamic boarding schools, especially pesantren which focuses more on language division as the output of the students. Many notices are explored from moral values, which can be internalized to students/students, not only learned from the linguistic aspect. There are still many texts in Indonesia worth exploring from various elements, especially moral values.

\section{Method}

This research is a qualitative descriptive type, with a literature study approach based on al-Qiro'ah al-Rosyidah volume 2, written by Abdul Fattah Shabri and Ali Utsman, where the 52nd printed book was published in 1953 AD. This book was chosen because, in addition to the text being written in Arabic literature, it was also the content of the book that contained the phenomena of daily activities, which character values could be learned. This book contains 60 story texts with characterizations of humans, animals, and other objects, the professions used in the text are past jobs such as farmers, fishermen, planters, carpenters, blacksmiths. This text illustrates that this book was written decades and even more than 100 years ago. The situation and condition and the text's atmosphere show that the natural atmosphere is still wide-spread, still traditionally not modern. The existing character values can be contextualized with the atmosphere and conditions of the present.

This paper analyzes an Arabic text that explores the good moral values in each book. The samples studied and analyzed were 18 texts from a population of 60 texts in volume 2 . The selection of this sample 
Text and Context: Exploring value of ....

was based on moral values in the text, and the number of 18 readers represented the character values that existed in the entire text of volume 2 . While book volume 2 is chosen based on the existing text, which is not too easy and not too difficult to understand the reading, the moral values contained are quite diverse than in the text volume 1 and volume 3. Other data besides the primary book al-Qiro'ah alRosyidah are also journals related to text and context studies as secondary data. This paper's data were collected through the reading note technique by giving codes in the text al-Qiro'ah al-Rosyidah, which lead to good morality values. Each text is read carefully and deeply, a conclusion made of what moral values are implied in the books. One by one and sheet by sheet, the text read and recorded according to the content contained therein. The data is then recorded in a notebook without any specific moral values or themes. The results of these notes followed by data analysis.

Data were collected from reading and recording results. From these data, then data reduction performed using mapping (selecting and sorting data). The next step is classifying the data according to the content with moral values. The data is then analyzed using the content analysis technique, exploring the textbook's character values, and contextualized it with values in real life according to the present era. Innovative and creative analysts always accompany this paper while maintaining the authenticity of the data.

\section{Literatur Review}

Character Values

Character and moral values exist to develop a person's ability to make the right decisions, maintain goodness, and realize that goodness

250 |VOL. 9 NO. 2 DECEMBER 2020 
in his life. (Komara, 2019) This series of character values are internalized and reflected in thoughts, emotions, and behavior. (Rawana et al., 2011) In its implementation, the cultivation of character values is manifested in the aspects of knowledge (cognitive), awareness or will (affective), and action (psychomotor). (Juraid et al., 2019; Herpratiwi et al., 2018) According to Ubaidillah et al. (2020), internalization of character values can be done through the practice of cultivation modes, such as planting, which consists of a) goal setting; b) seed selection; c) cultivation of land; d) planting seeds; 5) maintenance, and f) fertilization. The education system is a unique means to realizing this model. The process of cultivating character values through school institutions and self-development is called (Santoso et al. 2020a) as a micro process, while family, school, and community are the macro context. In any case the inculcation of these character values only reaches standard concepts without social procedures and practices, the results will be far from expectations because one will not get the experience and opportunity to adopt the character values. (Abdullah et al., 2019; Umami, Gani, \& Waskito, 2019)

In the above case, significant potential development needs to be applied to individuals as citizens who have the position of inheriting the nation's character values. (Umami et al., 2019) This character value is closely related to noble habits and behavior, which, according to Umami et al. (2019), align with universal values and religious traditions of the nation. Character is a personal quality that shapes a person's life. (Suprayitno, Rois, \& Arifin, 2019) However, eventhough the character elements are similar, the application of individual 
Text and Context: Exploring value of ....

characters, attitudes, and behaviors can differ from one country to another. (Ugurlu, 2014)

This is due to differences in socio-cultural, economic, and religious beliefs, which also influence different perspectives on specific core values. The application of local wisdom values also becomes an alternative in shaping cultured humans and as a guide in behavior, so that knowledge and character are created (Uge, Neolaka, \& Yasin, 2019) In the end, these character values become provisions and life skills for each individual. (Nurtanto et al., 2019; Lee, 2016) For this reason, when the existence of character values begins to decline, efforts can be made to reconstruct the philosophy of life, namely by rebuilding the principles of life so that they can be explored and developed by the current generation. They can be reappointed as character values. (Nurnaningsih, 2015)

In Indonesia generally the character values taught are around religion, nationalism, independence, cooperation, and integrity. (Santoso et al., 2020b; Prasetiyo et al., 2020) According to Santoso et al. (2020b), these values represent the Indonesian people's polite, peaceful, and gentle nature. The cost of social concern and the importance of respect for achievement are also considered by Sarkadi et al. (2020). It has been manifested in the zoning system regulated by the Regulation of the Minister of Education and Culture Number 44 of 2019, concerning the policy for new student admissions - even though it has not fully fulfilled educational goals in practice. Meanwhile, in Ghana, polite behavior is more identified with greetings, use of titles and honorifics, use of the words "please" and "thank you," use of a soft voice, and be quiet if necessary. (Thompson \& Anderson, 2019) Slightly different from Ghanaians, parents in Japan usually give first 252 |VOL. 9 NO. 2 DECEMBER 2020 
assignments to children under five years of age to exercise courage, independence, and responsibility (Setiawati, 2020) because children must do the first task without help from their parents.

\section{Character building}

Rokhman et al. (2014) define character education as a process of accumulating knowledge and wisdom to create a good life for humans. He explained that character education aims to internalize the values that are manifested through thoughts, emotions, and behavior. (Rawana et al., 2011) This value is in line with the principles that are trying to be applied in character education, emphasizing the importance of responsibility, discipline, patience, and persistence. (Hyoscyamina, 2011; Purwaningsih, 2012; Suarmini, N. W., Rai, N. G. M., \& Marsudi, 2016; (Subianto, 2013) Through existing values and principles, Sabunga, (2016) see that character education can contribute to national character formation. For him, character education is played by the function of educational institutions and community life, which is played by educational media. One of these media is the culture, which, according to Sabunga, (2016), is a strategy in shaping the character of the nation because it contains moral, spiritual, and multicultural principles. With the existence of character education, Syarif, (2016) view that the degradation of ethical and moral values can be postponed. Character education can build the character of students, which indirectly makes the character of the nation itself.

An individual also obtains the process of internalizing character education and educational institutions through the family. Family is considered the most effective place in cultivating character values and 
Text and Context: Exploring value of ....

shaping one's personality. (Hyoscyamina, 2011; Purwaningsih, 2012; Suarmini, N. W., Rai, N. G. M., \& Marsudi, 2016; Subianto, 2013) After obtaining values in the smallest line, namely family, individuals are provided with character education through educational institutions such as schools. For Rokhman, Hum, Syaifudin, \& Yuliati (2014), school is not only a place to transfer knowledge, but also to shape student attitudes, behavior, character, and leadership. Schools can accommodate existing values, such as local values, which, according to Fajarini, 2014) effectively foster and develop individuals. Furthermore, local deals taught in schools can cultivate good character in individuals such as integrity, togetherness, and tolerance. (Suyitno, 2012) However, in the process, character education must be carried out holistically. Suyitno (2012) provides an example by integrating character education through the curriculum. The integration of the two is then applied in classroom learning activities delivered by the teacher. Also, through reflection on the teacher himself, he becomes a role model for his students.

In character education, local-based values can teach students what they face. (Anggraeni, 2018) Nurabadi (2019) exemplifies this with a case study from SDN Pandanwangi, which applies character values through one of the mottos with culture-based values, which are expected to teach students the values that exist in Indonesia. This motto can be seen as a character depiction that reflects deep values, beliefs, and traditions patterns. It has been formed over the years and is an essential factor in schools' efficiency and success. (Ervin, 2019) According to Priyatna (2017), the internalization of existing values can be done with honest, loving, or moral feelings, which in turn will create moral acting as a form of character such as being religious, 254 |VOL. 9 NO. 2 DECEMBER 2020 
honest, disciplined, and hard work. Priyatna (2017) exemplifies this through the Pulo traditional village community's culture, which is expected to teach local-based values and norms.

Bugis culture, such as "Siri," can also be applied, teaching students to be individuals with high self-esteem. (M. Yusuf, 2014) Science learning models can also be inserted with existing local wisdom, one of which is through scientific reconstruction. Through existing local wisdom, these concepts are expected to foster a character of conservation for students. (Khusniati, 2014)

\section{Character in Islam}

The term "character education" has emerged massively as a concern to prepare students with good character. (Sutomo, 2014) Education and character in an Islamic perspective results from the process of implementing worship and muamalah (Islamic Sharia), which is based on faith, relying on the Al-Qur'an and Hadith. (Farida, 2016) In Surah Al-Qalam: 4, Allah emphasizes the importance of humans to have morals in all aspects of life and sent the Prophet Muhammad as a complement to human morals that deserves to be emulated. (Setiawan, 2014) In line with that, Fahyuni et al (2020) said that every human being in Islam is born in a sacred environment. Education is a determining factor for the quality of children's religion by providing meaningful learning to improve millennial children's quality. A study by Sokip et al (2019) shows that parents - in terms of character building - play a role in adopting Islamic values. In the findings of Tolchah \& Mu'ammar (2019), Islamic education can not 
Text and Context: Exploring value of ....

only maintain its existence for twenty-one centuries, but Islam also contributes to the formation of the character of education in Indonesia.

Islam uses the term "moral education" throughout history and has succeeded in shaping Muslims' character. (Sutomo, 2014) Moral comes from the Arabic Jama 'from the word' khuluqun 'which is linguistically defined as character, temperament,, manners, and actions. (Abdul Muqsith et al., 2017; Rokayah, 2015; Mahmud, 2017) According to Imam Al-Ghazali, morality is an effort that combines itself with a mental situation that is ready to bring up actions that are inherent in such a way and become a habit in everyday life. (Suryadarma \& Haq, 2015) In line with that, Ibn Sina also emphasized the importance of character building in the form of good morals from an early age. (Shuhari et al., 2019) In this case, Habibah (2015) divides morals into morals towards Allah, morals towards Rasullullah, morals towards oneself, morals towards family, morals towards society, and morals towards neighbors. The form of morality towards Allah as a human being is done by purifying Allah and praising him (Surah AlIsra ': 44), morals towards the apostles are manifested through justifying what the Prophet said, morals towards oneself through doing good for oneself, morals towards parents through giving respect, and morals towards others through actions that respect other opinions. (Mahmud, 2017)

Meanwhile, ethics comes from 'ethos,' which is defined as the character of decency or custom, while according to KBBI, it is defined as knowledge of moral principles. (Rokayah, 2015) Morals and ethics of religiosity influence a person to solve problems at work. (Azizan \& Razlina, 2015) Islamic ethics and morals contribute to education and contribute to the formation of the Islamic economic system. (Iswandi, 256 |VOL. 9 NO. 2 DECEMBER 2020 
2014) In line with that, the Al-Quran explains that a Muslim's morals towards the environment can contribute to preserving nature, developing responsibility, and caring for nature. (Fakhruddin, Suryadi, Hakam, \& Nurdin, 2018) Morals towards fellow humans contribute to global civilization as a peacemaker, a model of Islamic democracy, and an interpreter of religious tolerance through Islam's main characteristics. (Akbar, 2020) Islamic morals also color the nation's ideological values through the process of deliberation to solve problems faced by the Indonesian country. (Fuad, 2012) Also, strengthening Islamic behavior (morals) can enhance teachers' behavior and psychosocial, such as madrasa teachers. (Tambak \& Sukenti, 2020)

\section{Text and Context}

Text and context are two essential elements in human interaction and communication. The book will not have a complete and correct understanding without a context that includes the text. (Shen, 2012) Text is defined as a set of spoken and written language units with a specific meaning and purpose. (Ismayani, 2013) He added that the text is more systematic and structured and has certain elements in it. The book can be in the form of words, sentences, paragraphs, or discourse with unique characteristics. (Ismayani, 2013)

In contrast to Meyer, who defines text as written or spoken lingual units with specific language structures used to express particular meanings contextually. (Meyer, Halliday, \& Hasan, 1987) Skierkowski added that text and discourse are always the same, but there are slight differences, the discourse is more abstract and is a 
Text and Context: Exploring value of ....

realization of the text, while the text refers more to written and express material. (Skierkowski \& Wood, 2012) In line with that, Khaldun (2012) stated that text has a meaning that is not permanent and will experience a continuous sense of development. The book is a symbol that speaks of a mind that is always renewed by each generation of readers. Apart from continuing to exist because of its open nature, the relevance of the text will give birth to new meanings; it will also continue to speak under the surrounding context. (Kau, 2014) Book will always be a source of reference for readers because it always produces new understandings and interpretations. (N. Yusuf, 2015)

Text and context are two variables that are related to each other. According to Shen (2012), a book refers to a combination that can express all ideas in communication. At the same time, context is a character learned to show function in three aspects, namely field, tenor, and mode. In this case, Shen emphasized that text is produced and interpreted by several people who form a specific context through language and communication. So with that, text and context are two crucial elements in human contact where the book's production and understanding are influenced and limited by context. (Shen, 2012) In line with that, House (2006) explained that context and text are dynamically related to communication. An example is a relationship between linguistic products (book) and interpretive work that produces communication and discourse, shaping the context as much as the context forms that relationship. (Van Dijk, 2006) writes the relationship between text and context to explicitly explain and connect the facts of a book in different contexts.

There are various ways to read texts and contexts, namely linguistic interpretation, cognitive abilities, and sociocultural contexts 258 |VOL. 9 NO. 2 DECEMBER 2020 
in Sociology and Anthropology. Text and context, in this case, relate to one's culture. A built and attached culture to an individual fosters different understandings and interpretations of a book. (Van Dijk, 2006) Strengthening some of these statements, Lukin (2017) then explains that context provides a means of connecting the reader to a cultural context where this explanation is intended to describe each cultural ideology's function and origin. Last Van Dijk (2006) said that a functional perspective builds context with three aspects: field, period, and mode. Then, Parish (2019) added that context emerged because the author formed it through writing text, but often what is registered does not pay attention to the context. The writing of the book and context is no longer relevant and related.

\section{Result and Discussion}

The textbook al-Qiro'ah al-Rosyidah is a reading book widely taught in Islamic boarding schools as material for Mutala'ah lessons. The texts in this book are various literary texts that can be categorized into types of fable stories. Texts in which the conditions are filled with character values that can be internalized by students or readers.

\section{Overview of the al-Qiro'ah al-Rosyidah textbook}

The textbook al-Qiro'ah al-Rosyidah was written more than a century ago, where the 52nd printed book was published in 1953 AD. This book was written by two great people named Abdul Fattah Shabri and Ali Umar. Published by Maktabah al-Hidayah institute in Surabaya. The minister of education suggested that this book is for beginners or elementary school students. The book is written in 3 volumes, each of which is described in the following table: 
Table 1

Composition of al-Qiroah al-Rosyidah Textbook

\begin{tabular}{llll}
$\begin{array}{c}\text { Book } \\
\text { Volume }\end{array}$ & \multicolumn{1}{c}{ Characteristics } & $\begin{array}{c}\text { Total Text / } \\
\text { Title }\end{array}$ & $\begin{array}{c}\text { Number } \\
\text { of pages }\end{array}$ \\
\hline Volume one & $\begin{array}{l}\text { Presented in a more } 60 \text { texts } \\
\text { straightforward and } \\
\text { more uncomplicated } \\
\text { language, and the text } \\
\text { is relatively short. }\end{array}$ & \\
\hline Volume two & $\begin{array}{l}\text { Presented pages } \\
\text { improved language or }\end{array}$ & \\
\hline & $\begin{array}{l}\text { vocabulary, but still } \\
\text { relatively simple. The } \\
\text { readings are written } \\
\text { short; some are slightly } \\
\text { longer but are broken } \\
\text { down into chapters. }\end{array}$ & \\
\hline & &
\end{tabular}

Volume three $\begin{aligned} & \text { The themes are } 65 \text { texts } \\ & \text { elevated a little higher, } \\ & \text { and the vocabulary is } \\ & \text { slightly more } \\ & \text { complicated. The text } \\ & \text { is written longer, }\end{aligned}$

Table 1 describes the textbook contents al-Qiro'ah al-Rosyidah, where each volume has a gradation in the level of complexity of understanding a text. The gradations show from very simple to elaborate, both in the aspect of presenting the story in the text, as well as the vocabulary used. The book is written in Arabic on each page equipped with a row of meanings from difficult words listed in the text. The amount of text has also been seen from table 1 ; there is a slight increase. In volumes 1 and 2, there are similarities in the number 260 |VOL. 9 NO. 2 DECEMBER 2020 
of books, but there are differences in the short and length of the texts presented. The text in volume 1 is shorter than the text in volume 2 . These differences are reflected in the number of pages that have been shown. As Setyawan said, material books that meet learning standards for students are books that are arranged with pleasing material gradations. Namely, the presentation of material from simple to more complex, both in terms of the lack of language, vocabulary, and the text's content in it. (Setyawan, Basit, \& Fathoni, 2018)

The textbook al-Qiro'ah al-Rosyidah has four interests and features that make this book still exist and used as a material in several schools and Islamic boarding schools: 1) The Arabic vocabulary used is light straightforward, making it easy for students to understand the text. 2) The book is written in prose and poetry (poetry). The book has triggered readers to explore several things in it, such as language units in the form of words, phrases, clauses, sentences and discourses. In addition, prose is also seen as an effective means of conveying good moral messages to readers, especially morality related to character values. 3) It is easily adaptable by students in writing their personal and other people's experiences. 4) The text contains daily stories that flow and can be practiced in everyday activities.

The four characteristics that constitute this book's contents are the writer's ideas and experiences, which are presented neatly so that readers and students can practice the messages contained in their activities. Not only can it be applied in terms of how to express an idea in writing, but it also can be imitated and practice its good values in living life. 
In the textbook al-Qiro'ah al-Rosyidah in volume 2, there are 60 texts divided into three core characteristics. First, there are 55 texts written in prose or fiction and five texts in poetry. The prose is a narrative work that says something imaginary, imaginative, not based on reality. (Hairuddin \& Radmila, 2017) Second, the story characters who become symbols in the text consist of things that exist in the universe and are real even though the stories are fictional, such as animals, humans, objects (water, pearls, boats, fields). Third, each text is accompanied by a picture that reflects the description of events in the book. This text is in line with Loarid's research, which shows that pictorial stories can build and stimulate children to think critically. (Loarid, Waluyanto, \& Zacky, 2015) Overall, the textbook al-Qiro'ah al-Rosyidah has guided in the form of examples of good character values, which lead readers to adopt and practice morals without being patronized.

\section{The Texts in the Textbook al-Qiro'ah al-Rosyidah that Contain Character Values}

The textbook al-Qiro'ah al-Rosyidah contains many messages to impart to readers, which are presented in the form of stories relevant to the world of children at various levels of education both in formal and informal or Islamic boarding schools. The contents of good values and norms in the textbook al-Qiro'ah al-Rosyidah follow the context of the daily values of the readers' daily activities. Examples and role models of figures in the text can be easily internalized by readers due to the simple language and presented attractively. The values in the textbook al-Qiro'ah al-Rosyidah are shown in table 2 below.

262 |VOL. 9 NO. 2 DECEMBER 2020 
Table 2

Character values that have been presented in the textbook al-Qiro'ah al-Rosyidah

\begin{tabular}{|c|c|c|}
\hline Title & Summary of Contents & Code \\
\hline جزاء الصدق & $\begin{array}{l}\text { The honesty of a farmer who takes good } \\
\text { care of his master's field. Regardless of } \\
\text { the slander raised by his neighbors. In } \\
\text { the end, the farmer received a reward } \\
\text { from his employer. }\end{array}$ & Honest \\
\hline الأنجاح & $\begin{array}{l}\text { Employers announce the recruitment of } \\
\text { secretaries, many young people apply, } \\
\text { and interviews. Sometime after the } \\
\text { interview, it was revealed who was } \\
\text { elected secretary. He was a young man } \\
\text { with good character, cleaned his sandals } \\
\text { before entering the room, closed the } \\
\text { door gently and was calm, clean, } \\
\text { orderly, said greetings, answered every } \\
\text { question swiftly and politely. He is a } \\
\text { young man of good character. }\end{array}$ & $\begin{array}{l}\text { Having good } \\
\text { character is the } \\
\text { key to success }\end{array}$ \\
\hline العندليب & $\begin{array}{l}\text { Constant gentleness can break through } \\
\text { and even knock down walls of pride. }\end{array}$ & Humble \\
\hline الحمامة و النملة & $\begin{array}{l}\text { The ants had encountered difficulties in } \\
\text { a river and were helped by a dove by } \\
\text { throwing a branch. Likewise, when the } \\
\text { dove is in danger, the ant helps by biting } \\
\text { the hunter. }\end{array}$ & $\begin{array}{l}\text { Helping } \\
\text { other }\end{array}$ \\
\hline الزنبار & $\begin{array}{l}\text { The two beasts already possessed } \\
\text { dangerous vices, but behind that, they } \\
\text { had a medicine that was enjoyed by } \\
\text { mankind. }\end{array}$ & $\begin{array}{l}\text { Take lessons } \\
\text { from experience }\end{array}$ \\
\hline مزية التصوير & $\begin{array}{l}\text { Betrayal committed by the host to his } \\
\text { guest (a good painter) by taking the } \\
\text { guest's property while sleeping. The } \\
\text { betrayal was revealed by the painter's } \\
\text { skill to draw the traitor's family clearly }\end{array}$ & $\begin{array}{l}\text { Betrayal } \\
\text { Amanah }\end{array}$ \\
\hline الأمانة كنز & $\begin{array}{l}\text { A child who had found the wallet of a } \\
\text { wealthy merchant owner, he returned it } \\
\text { with everything intact. He was appointed } \\
\text { as a merchant student until he became }\end{array}$ & $\begin{array}{l}\text { Sincere and } \\
\text { trustworthy }\end{array}$ \\
\hline
\end{tabular}




\begin{tabular}{|c|c|c|}
\hline Title & Summary of Contents & Code \\
\hline & $\begin{array}{l}\text { the most professional and most paid } \\
\text { worker and led the merchant's entire } \\
\text { company. This is due to his intelligence, } \\
\text { sincerity, and trustworthiness. }\end{array}$ & \\
\hline المر اكب & $\begin{array}{l}\text { A boat made of wood or iron, which is } \\
\text { very strong, can carry thousands of } \\
\text { passengers, vehicles, and merchandise; if } \\
\text { there is a hole/leak, the seed will drown } \\
\text { the ship and all its contents. }\end{array}$ & $\begin{array}{l}\text { Don't } \\
\text { underestimate the } \\
\text { danger, however } \\
\text { small }\end{array}$ \\
\hline جماعة الفيران & $\begin{array}{l}\text { Allah has inspired the animals/mice so } \\
\text { that the healthy help the weak. The rats } \\
\text { that were still strong had helped and } \\
\text { supported the old and weak rats. }\end{array}$ & Mutual help \\
\hline هدية الفيران & $\begin{array}{l}\text { Someone has been gifted a box of mice } \\
\text { for killing his lovely cat. }\end{array}$ & $\begin{array}{l}\text { The reply will } \\
\text { come according } \\
\text { to what is done }\end{array}$ \\
\hline أي مهنة تختار & $\begin{array}{l}\text { Every night parents tell their children at } \\
\text { bedtime by asking questions about their } \\
\text { respective professions that they want to } \\
\text { achieve. }\end{array}$ & Uswah hasanah \\
\hline حيلة العنكبوت & $\begin{array}{l}\text { A spider had tried to save itself by } \\
\text { perching on a stick stuck by a man at the } \\
\text { edge of the pool. }\end{array}$ & Self management \\
\hline الماء & $\begin{array}{l}\text { Water can enter and adjust to the place } \\
\text { in any form }\end{array}$ & Adaptation \\
\hline و الفلاح و اللفت & $\begin{array}{l}\text { Farmers are indigent and diligent in the } \\
\text { fields so that their crops are good and } \\
\text { get awards from the government. While } \\
\text { the lazy rich are jealous and show their } \\
\text { agricultural products to the government, } \\
\text { what they get is not a gift. }\end{array}$ & $\begin{array}{l}\text { Sincere, } \\
\text { greedy }\end{array}$ \\
\hline عن لاتسأل وسل المرء & $\begin{array}{l}\text { A farmer killed a bird because it had } \\
\text { damaged his crop. The other bird was } \\
\text { crying, depressed when it met the } \\
\text { farmer, worried about being killed like } \\
\text { his friend. "The farmer said: I did not } \\
\text { kill you, you are good, do not destroy } \\
\text { crops." }\end{array}$ & Responsible \\
\hline
\end{tabular}

264 |VOL. 9 NO. 2 DECEMBER 2020 


\begin{tabular}{|c|c|c|}
\hline Title & Summary of Contents & Code \\
\hline الخادم و السمك & $\begin{array}{l}\text { A servant buys fish in the market with a } \\
\text { long queue; he goes into the shop, takes } \\
\text { a large fish to weigh, then pays the } \\
\text { cashier. Before leaving, the seller calls to } \\
\text { return the fish. But buyers smell fish as } \\
\text { if talking about drowning in the sea. The } \\
\text { seller discouraged. Buyers can bring fish } \\
\text { home. }\end{array}$ & Clever strategy \\
\hline والجنين & $\begin{array}{l}\text { Two teenagers (Ramadan and Sulaiman) } \\
\text { are friends; Sulaiman invites Ramadan } \\
\text { to join the battle, he rejects it because he } \\
\text { is not part of him. Sulaiman was angry, } \\
\text { and their friendship broke. Sulaiman and } \\
\text { his friends swam in the sea, he drowned } \\
\text { and asked for help, while his friends ran } \\
\text { ignorantly, while Ramadan heard from } \\
\text { the shore immediately swam to help } \\
\text { Sulaiman. }\end{array}$ & Be brave \\
\hline الصياد و الأسد & $\begin{array}{l}\text { One day a man was hunting in the forest, } \\
\text { knowing that a lion was after him. The } \\
\text { hunter could not possibly exceed the } \\
\text { lion's speed. He strategizes to hide on } \\
\text { the edge of a cliff by making a } \\
\text { scarecrow out of the wood he is wearing. } \\
\text { So that it pounced on the wood and } \\
\text { entered a ravine }\end{array}$ & Clever strategy \\
\hline
\end{tabular}

Table 2 has shown that the message in each story in the text reflects good values which can be mapped into several points, including: honest, humble, sincere, knowledgeable, intelligent and smart, brave, responsible, adaptable, appreciative no matter how small, please help, help each other, uswah hasanah, smart strategies, neat, self-management, taking lessons from every experience. This whole message can be used as a character education model for children of all ages, pre-adolescents, adolescents, and adults. In line with that, education and character are the implications of a worship and good 
Text and Context: Exploring value of ....

relationship with God, humans and other creatures in this universe. (Farida, 2016) The purpose of humans created by God on this earth is to worship, while the existence of worship can be reflected through morals in daily behavior. As the Prophet's words which read: "That I was sent by Allah to perfect noble morals". It is also affirmed in the alQur'an surah al-Qalam "And indeed you are truly virtuous and noble". (QS. 68: 4) Good morals can be obtained through education and an environment that practices Islamic values, because every human being is born in a holy state like a white paper that is ready to be inscribed by the surrounding environment, including education. (Sokip et al, 2019)

The character values implied from the text of al-Qiro'ah alRosyidah as displayed in table 2 indicate the relevance of the mission of Islamic education (in Islamic boarding schools or other Islamic educational institutions), (Suryadarma \& Haq, 2015) which is to teach and practicing character education based on the Koran by promoting moral education, (Indrawan, 2016) The Qur'an has provided a real solution for Muslims to develop spiritual, emotional, and intellectual awareness which is not only a display or theory, but must be translated into everyday life behavior. (Rustini, 2018) In line with that, character education is the education of values, morals, character, and character education that transforms the ability of students to decide whether or not they are good, and embodies the goodness of every act and speech. (Nasional, 2011)

Character values such as the attitude of virtuous youths that are reflected in their every movement have led to success, have coherence with the aim of education in Indonesia which seeks to create a nation that is faithful, devoted to God, with noble character, has good 266 |VOL. 9 NO. 2 DECEMBER 2020 
knowledge, and has insight nationality. (Sujana, 2019) In the preindependence era, education aimed to instill character in students through the principles of morality, ethics and etiquette that underlie every behavior in everyday life. (Sabarudin, 2015) In the era of democracy under the leadership of Soekarno, the formation of national character was centered on Pancasila lessons, where every student must be able to internalize the points of Pancasila in every activity. (Gunawan, 2013) In line with the times and the echo of reforms, a competency-based curriculum was rolled out which initiated the birth of character. (Nury Batubara \& Aman, 2019) All of this is also in line with the character education initiated by Imam al-Ghozali, that every child must be given faith education, moral education, social education, and physical education. (Abidin, 2019)

The text presented in this book is in the form of literary works, namely prose and poetry. It has a meaningful existence in the community, especially children at elementary school/madrasah ibtidaiyyah to madrasah Aliyah. Given that literary works, apart from having a character of entertainment nuances that are not easily bored to read repeatedly, also contain messages to be imparted from every wisdom in each text. As Muassomah said, literature-based character education has been useful for adolescents, at which age children like to read entertainment books, and indirectly the good values they read have been internalized. (Muassomah et al., 2020) The textbook alQiro'ah al-Rosyidah also describes a Muslim community's culture in carrying out its daily activities, even though the story is presented in fiction. This book also colors human civilization's wealth with the 
Text and Context: Exploring value of ....

expertise and ability to give reasonable values in a literary work. (Zamroni, 2011)

Prose and poetry are like text models in the al-Qiro'ah alRosyidah textbook, in which the literary works supporting character education. Indeed, literature is dense with messages and values of life directly related to the formation of student character. (Muassomah et al., 2020) In addition to developing Arabic, this book also develops cognitive, affective, psychomotor aspects, personality, and student identity. In line with that, literature is also a learning media that can be receptive and expressive in internalizing good values (Rondiyah, Wardani, \& Saddhono, 2017). Receptive, done by selecting teaching materials and managing learning in building student character. Expressive literature is used as a medium for character formation by managing emotions, feelings, enthusiasm, ideas, views, ideas, and readers' thoughts. In other words, students who understand their literary texts will easily be adaptive to the values contained in them.

\section{Contextualization of Character Values Contained in the Book al-Qiroah al-Rosyidah}

This book provides an overview of the activities carried out by a person every day in living his life during social society. Every side of life cannot be separated from character values, especially when interacting with other people. This book is presented in a story with the main characters of humans, animals, and even plants. That each of us, as Allah's creatures on earth, cannot be separated from the relationship between humans and between other creatures, apart from indeed a relationship with God. All of this is very closely related to ethics, social and interacting behavior. Whether it's activities related to religion, socio-culture, politics, and even work matters. Every human 268 |VOL. 9 NO. 2 DECEMBER 2020 
movement cannot be separated from norms and manners. This book has attempted to contextualize and internalize the character values as set out in table 2 .

Human figures play character values such as patience, trustworthiness, honesty, sincerity, and responsibility in the textbook al-Qiroah al-Rosyidah. The characters at play are farmers, servants, painters, nomads, small children, and traders, but the character of farmer dominates from this overall roles. This role illustrates that work is done with great patience will get good results. In line with that, any work carried out with full responsibility and sincerity, accompanied by a high mandate, will get a reward in kind, both from the results of the works and from the people around. A smart strategy is a form of someone who must be intelligent, educated, and knowledgeable. This can make a person not easily deceived and fooled by others. With education, a person gets a noble degree and obtains the happiness of the hereafter. As stated in the letter al-Mujadalah: 11 that Allah will elevate the rank of those who believe and have knowledge. (Djunaid, 2014)

Cooperation and help, which is described in a mouse's role, represents the spirit of an individual or group doing an action and activity without expecting a reward; this is done for personal and collective interests. In line with that, please help a difficult job becomes easier; something heavy becomes light. The values that can be taken from this cooperation are togetherness, unity, willingness to sacrifice, socialization, and solidarity. Cooperation and help can be contextualized with an attitude of cooperation in doing any work today; this has fostered a voluntary and familial attitude, easing the 
Text and Context: Exploring value of ....

burden that must be borne, fostering good social relations between community members.

\section{Conclusion}

It turns out that the al-Qiro'ah al-Rosyidah textbook written in Arabic has revealed the dimension of "morality" of the text, beyond conventional studies which only reveal the "linguistic" aspect of a text. The text of al-Qiro'ah al-Rosyidah does not only equip students with language and its various elements, but instills character values in students. In addition, the text of al-Qiro'ah al-Rosyidah is presented in the form of a story which is seen as an effective medium in conveying moral messages and values of character education in it. Along with that, the story has attracted students' interest in learning character, because there is a space for the adoption of values with their own awareness without dominating the teacher in the educational process.

The al-Qiro'ah al-Rosyidah textbook is one of the treasures of the archipelago which has relevance as teaching material / material in various Islamic boarding schools in Indonesia, in line with other turats (yellow books) teach worship and muamalah, also language, but there are two differences that stand out. First, al-Qiro'ah al-Rosyidah textbooks focused more on moral education, while turas books teach fiqh, such as Fathul Qarib and Fathul Mu'in, tauhid such as alJawahir al-Kalamiyah, Sufism like al-Hikam, and the Arabic sciences like al-Jurumiyah, Ibn Aqil, Nazam al-Maqsud, and Jauharul Maknun. Second, turas books presenting the material more on theories and rules that students must memorize and apply, while al-Qiro'ah al-Rosyidah textbooks are presented in the form of light stories which can easily be translated and actualized by students in daily activities.

270 |VOL. 9 NO. 2 DECEMBER 2020 
The use of the concept of critical analysis in this research is carried out by understanding the reality of events or activities in the alQiro'ah al-Rosyidah text, such as situations, objects, people, animals, and the statements that are written behind them; some meanings exist. The critical analysis also requires the researcher's courage to express opinions critically, either supporting or blaspheming the text. This concept can also determine the contextualization of the values of the characters depicted in the past drawn by experiences in the present.

The research has limitations on one volume in the textbook alQiro'ah al-Rosyidah, so that good values and norms are reflected in limited, less varied activities. This research suggests analyzing the same book as a whole so that the values extracted are more diverse according to the current activity description.

\section{References}

Abdul Muqsith, A., Zaharah, H., Maisarah, A. M., \& Mohd Ridhuan, M. J. (2017). Masalah Etika dan Akhlak Pelajar Kemahiran Kejuruteraan: Analisis Keperluan. JuKu: Jurnal Kurikulum \& Pengajaran Asia Pasifik. 5(2), 34-45. https:// juku.um.edu.my/ article/view/8219

Abdullah, I., Hudayana, B., Setiadi, Kutanegara, P. M., \& Indiyanto, A. (2019). Beyond School Reach: Character Education in Three Schools in Yogyakarta, Indonesia. Journal of Educational and Social Research. https://doi.org/10.2478/jesr2019-0032

Abidin, M. N. Z. (2019). Pendidikan Karakter Menurut Islam dalam Perspektif Imam Al-Ghazali. Jurnal Akademika.

Akbar, F. M. (2020). Peranan dan Kontribusi Islam Indonesia pada Peradaban Global. Jurnal Indo-Islamika. https://doi.org/ 10.15408/idi.v10i1.17522

Anggraeni, L. D. (2018). Implementasi Pendidikan Karakter "Kearifan Lokal Malang” Pada Ekstrakurikuler Tari Topeng Bapang HERITAGE OF NUSANTARA: INTERNATIONAL JOURNAL OF RELIGIOUS LITERATURE AND HERITAGE $\mid 271$ 
dan Karawitan Jawa Di Sd Taman Muda 02 Malang.

Anis, M. Y., Arifuddin, A., \& Farhah, E. (2015). Pengembangan Tema Dalam Buku Al-Qira'ah Ar-Rasyidah untuk Pelatihan Menulis Kreatif Bahasa Arab. Arabiyat: Jurnal Pendidikan Bahasa Arab Dan Kebahasaaraban. 2 (2), 144-153. https:// doi.org/10.15408/a.v2i2.2090

Ardianty, D. (2014). Serat Sindujoyo: Suntingan Teks dan Analisis Fungsi Sosial Naskah bagi Masyarakat Kabupaten Gresik (Doctoral dissertation, Universitas Airlangga). Retrieved from http://repository.unair.ac.id/14380/

Azizan, H. M., \& Razlina, H. J. (2015). Relationship Between Workplace Incivility, Job Attitudes and Muslim Religiosity Personality among Trade Union Members. Global Journal AlThaqafah. 5(2), 43-51. https://doi.org/ 10.7187/ gjat 892015 .05 .02

Christianna, A. (2018). The Aesthetic of Damar Kurung Painting (Doctoral dissertation, Petra Christian University). Retrieved from http://artesh.itb.ac.id/

Djunaid, H. (2014). Konsep Pendidikan dalam Alquran (Sebuah Kajian Tematik). Lentera Pendidikan: Jurnal Ilmu Tarbiyah Dan Keguruan. https://doi.org/10.24252/lp.2014v17n1a10

Fahyuni, E. F., Wasis, Bandono, A., \& Arifin, M. B. U. B. (2020). Integrating Islamic Values and Science for Millennial Students' Learning on Using Seamless Mobile Media. Jurnal Pendidikan IPA Indonesia. 9(2), 231-240. https://doi.org/ 10.15294/ jpii.v9i2.23209

Fajarini, U. (2014). Peranan Kearifan Lokal dalam Pendidikan Karakter. Sosio Didaktika: Social Science Education Journal. https://doi.org/10.15408/sd.v1i2.1225

Fakhruddin, A., Suryadi, A., Hakam, K. A., \& Nurdin, E. S. (2018). The Development of Learning Content of Islamic Religious Education (IRE) Courses on Environmental Conservation in Higher Education. IOP Conference Series: Earth and Environmental Science. Vol. 145, No. 1, p. 012-125 https://doi.org/10.1088/1755-1315/145/1/012125

Farida, S. (2016). Pendidikan Karakter dalam Prespektif Islam. Kabilah, 1(1), 10. http://ejournal. kopertais4.or.id/ madura/

272 |VOL. 9 NO. 2 DECEMBER 2020 
index.php/kabilah/article/view/1724.

Febrianti, N., Abdulkarim, A., Malihah, E., \& Fitriasari, S. (2020). Analisis Muatan Kajian Gender pada Buku Teks Pendidikan Kewarganegaraan di Perguruan Tinggi. Jurnal Inspirasi Pendidikan. https://doi.org/10.21067/jip.v10i1.4328

Fuad, F. (2012). Islam dan Ideologi Pancasila, Sebuah Dialektika. Lex Jurnalica.

Gunawan, R. (2013). Pembelajaran Nilai-nilai Pahlawan Kemerdekaan Soekarno dalam Rangka Mengembalikan Karakter Bangsa Indonesia. Journal Widya Non-Eksakta. 10(1), 70-77. https://doi.org/10.21067/jip.v10i1.4328

Habibah, S. (2015). Akhlak dan Etika Dalam Islam. Jurnal Pesona Dasar, 1(4), 73-87. repository. unsyiah.ac.id/ PEAR/article/ view/7527

Hairuddin, D., \& Radmila, K. D. (2017). Hakikat Prosa dan Unsurunsur Cerita Fiksi. Jurnal Bahasa. https://osf.io/ preprints/inarxiv/5wt9f/

Harahap, Z. H. (2017). Pendidikan Karakter Berbasis Nilai Moral dan Nilai Kebangsaan. 1(1), 407-410. http://digilib. unimed.ac.id/27557

Herpratiwi, Setiyadi, A. B., Riswandi, Ertikanto, C., \& Sugiyanto. (2018). Building Students' Character in Elementary School through the Scientific Method: A case study of the Lampung Province. Pertanika Journal of Social Sciences and Humanities. 26(3), 1547-1561. http://pertanika.upm.edu.my/

Hyoscyamina, D. E. (2011). Peran keluarga dalam membangun karakter anak.,. Jurnal Psikologi, 10(2), 144-152.

Indrawan, I. (2016). Pendidikan Karakter dalam Perspektif Islam. AlAfkar: Jurnal Keislaman \& Peradaban. https://doi.org/ 10.28944/afkar.v2i1.90

Ismayani, R. (2013). Kreativitas Dalam Pembelajaran Literasi Teks Sastra. Jurnal Ilmiah Program Studi Pendidikan Bahasa Dan Sastra Indonesia.

Iswandi, A. (2014). Peran Etika Qur'ani terhadap Sistem Ekonomi Islam. Al-Iqtishad: Journal of Islamic Economics. 6(1), 143154. https://doi.org/10.15408/ijies.v6i1.1528 
Juraid, Hamzah, B., Mahpudz, A., \& Khaldun, R. I. (2019). Implementation and Development of Adiwiyata Schools to Realize Character of Students Care for Environment. International Journal of Scientific and Technology Research.

Kau, S. A. (2014). Hermeneutika Gadamer dan Relevansinya dengan Tafsir. Farabi: Journal of Ushuluddin \& Islamic Thought, 11(2), 109-123. Retrieved from https://journal. iaingorontalo.ac.id/index.php/fa/article/view/782

Khaldun, R. (2012). Hermeneutika Khaled Abou El Fadl: Sebuah Upaya Untuk Menemukan Makna Petunjuk Kehendak Tuhan Dalam Teks Agama. Jurnal Edu-Islamika, 3(1).

Khusniati, M. (2014). Model Pembelajaran Sains Berbasis Kearifan Lokal dalam Menumbuhkan. Karakter Konservasi. Indonesian Journal of Conservation, 3(1).

Komara, E. (2019). Generation of Literation and Strengthening of National Character Education. Journal of Advanced Research in Dynamical and Control Systems. 3(1), 15-26. DOI: https://doi.org/10.2121/.v3i1.1313

Lee, A. (2016). Implementing Character Education Program through Music and Integrated Activities in Early Childhood Settings In Taiwan. International Journal of Music Education. 34(3), 340-351. https://doi.org/10.1177/0255761414563195

Loarid, J., Waluyanto, H. D., \& Zacky, A. (2015). Perancangan Buku Cergam Interaktif untuk Menumbuhkan Sikap Berpikir Kritis Anak melalui Kebiasaan Membaca. Jurnal DKV Adiwarna. 1(6), 12.

Lukin, A. (2017). Ideology and the Text-in-context Relation. Functional Linguistics. https://doi.org/10.1186/s40554-0170050-8

Mahmud, A. (2017). Akhlak terhadap Allah dan Rasulullah. Jurnal Wawasan Keislaman, 11(2), 57-68.

Maknun, M. L., \& Muzayanah, U. (2020). Contextualization of Suluk Candra's Character Values. Heritage of Nusantara: International Journal of Religious Literature and Heritage. https://doi.org/10.31291/hn.v9i1.563

Mannuhung, S. (2019). Penanggulangan Tingkat Kenakalan Remaja Dengan Bimbingan Agama Islam. To Maega | Jurnal 274 |VOL. 9 NO. 2 DECEMBER 2020 
Pengabdian Masyarakat, 2(1), 9. https://doi.org/ 10.35914/ tomaega.v2i1.234

Mashuri, M. (2017). Ilustrasi dalam Serat Sindujoyo. Jurnal Masyarakat dan Budaya. 9(1), 105-118.https://doi.org/ 10.14203/jmb.v19i1.400

Meyer, C. F., Halliday, M. A. K., \& Hasan, R. (1987). Language, Context, and Text: Aspects of Language in a Social-Semiotic Perspective. TESOL Quarterly. https://doi.org/ 10.2307/ 3586740

Mirnawati, M. (2019). Analisis Semiotika dalam Teks Al-Barzanji. `A Jamiy: Jurnal Bahasa Dan Sastra Arab. 8(1), 31-52. https://doi.org/10.31314/ajamiy.8.1.31-52.2019

Muassomah, Abdullah, I., Istiadah, Mujahidin, A., Masnawi, N., \& Sohrah. (2020). Believe in Literature: Character Education for Indonesia's Youth. Universal Journal of Educational Research. https://doi.org/10.13189/ujer.2020.080605

Muhsin, M. (2012). Tata Cara Pelaksanaan Shalat Jum'at (Studi Naskah "Sulûk Al-Jâddah Fî Bayân Al-Jum'ah" Karya Syeikh Nawawi al-Bantani). NUANSA: Jurnal Penelitian Ilmu Sosial Dan .... , 9(2). DOI: http://dx.doi.org/ 10.19105/ nuansa. v9i2.159

Mujahid, A. (2016). Tafsir Al-Quran Dalam Naskah [Majaz]: Studi Filologis dan Analisis Isi. Jurnal Ilmiah Ilmu Ushuluddin, 11(2), 129. https://doi.org/10.18592/jiu.v11i2.736

Mulyani, H. (2016). Unsur Kebudayaan Jawa Dalam Teks Pamoripun Saréngat, Tarékat, Kakékat, Lan Makrifat. Jurnal IKADBUDI. 3(10). https://doi.org/10.21831/ ikadbudi.v3i 10. 12036

Mutohar, P. M. (2020). Turnitin of Design of Character-Based Learning in Islamic Elementary Schools with a Full Day System. http://repo.iain-tulungagung.ac.id/15282

Nasional, K. P. (2011). Panduan Pelaksanaan Pendidikan Karakter. Guideline.

Niampe, L. (2013). Pengaruh Islam dalam Kebudayaan Lokal di Button: Satu Kajian Berdasarkan Teks Sarana Wolio. ElHarakah (Terakreditasi). 14(2), 243-267. https://doi.org/ 10.18860/el.v14i2.2314 
Nurnaningsih, N. (2015). Rekonstruksi Falsafah Bugis dalam Pembinaan Karakter: Kajian Naskah Paaseng Toriolo Tellumpoccoe. Jurnal Lektur Keagamaan. 13(2), 393-416. https://doi.org/10.31291/jlk.v13i2.232

Nurtanto, M., Sofyan, H., Fawaid, M., \& Rabiman, R. (2019). Problem-Based Learning (PBL) In Industry 4.0: Improving Learning Quality Through Character-Based Literacy Learning and Life Career Skill (LL-LCS). Universal Journal of Educational Research. 13(2), 393-416. https://doi.org/ 10.13189/ujer.2019.071128

Nury Batubara, U., \& Aman, A. (2019). Perkembangan Pembelajaran Sejarah Pasca Kemerdekaan-Reformasi. Jurnal Pendidikan Sejarah. https://doi.org/10.21009/jps.081.02

Prasetiyo, E., Suyatno, \& Baswedan, A. R. (2020). Implementation Of Character Education By Establishing A Special Task Force In Muhammadiyah Karangkajen Elementary School. International Journal of Scientific and Technology Research.

Priyatna, M. (2017). Pendidikan Karakter Berbasis Kearifan Lokal. Edukasi Islami: Jurnal Pendidikan Islam, 5(10).

Purwaningsih, E. (2012). Keluarga dalam Mewujudkan Pendidikan Nilai sebagai Upaya Mengatasi Degradasi Nilai Moral. Jurnal Pendidikan Sosiologi Dan Humaniora.

Rawana, J. R. E., Franks, J. L., Brownlee, K., Rawana, E. P., \& Neckoway, R. (2011). The Application of A Strength-Based Approach of Students' Behaviours to The Development of A Character Education Curriculum for Elementary and Secondary Schools. Journal of Educational Thought.

Rokayah. (2015). Penerapan Etika dan Akhlak dalam Kehidupan Sehari-Hari 15. Terampil. 2(1), 15-33. https://doi.org/ 10.24042/terampil.v2i1.1279.

Rokhman, F., Hum, M., Syaifudin, A., \& Yuliati. (2014). Character Education for Golden Generation 2045 (National Character Building for Indonesian Golden Years). Procedia - Social and Behavioral Sciences. https://doi.org/10.1016/ j.sbspro. 2014. 05.197

Rondiyah, A. A., Wardani, N. E., \& Saddhono, K. (2017). Untuk Meningkatkan Pendidikan Karakter Kebangsaan Di Era Mea

276 |VOL. 9 NO. 2 DECEMBER 2020 
(Masayarakat Ekonomi Asean). The 1st Education and Language International Conference Proceedings Center for International Language Development of Unissula. (Vol. 1, No. 1).http://jurnal.unissula.ac.id/index.php/ELIC/article/view/123

Roviin, R. (2018). Analisis Buku Teks Al 'Arabiyah Li Al Nasyi' in Karya Mahmud Ismail Shini, Dkk. Jurnal Al Bayan: Jurnal Jurusan Pendidikan Bahasa Arab. 10(1), 36-53. https://doi.org/10.24042/albayan.v10i01.2594

Rustini, T. (2018). Pendidikan Karakter Anak Usia Dini. Cakrawala Dini: Jurnal Pendidikan Anak Usia Dini. https://doi.org/ 10.17509/cd.v3i1.10321

Sabarudin, M. (2015). Pola dan Kebijakan Pendidikan Islam Masa Awal dan Sebelum Kemerdekaan. Jurnal Tarbiya UIN SGD.

Sabunga, B. (2016). Nilai-nilai Karakter dalam Pertunjukan Wayang Golek Purwa. Sosio Religi: Jurnal Kajian Pendidikan Umum, 14(1).

Santoso, F. P., Mulyoto, Djono, \& Hanif, M. (2020). Inculcating Character Values to The Student of Polytechnic Atmi Surakarta Vocational School. Universal Journal of Educational Research. 8(2):417-424. https://doi.org/ 10.13189/ujer. 2020. 081712

Santoso, T., Sujianto, Afianto, D., Saputro, D., Sabardila, A., Fauziati, E., \& Markhamah. (2020). Character Education Values in Revised Edition of The Indonesian Language Learning Curriculum for Year 10. Universal Journal of Educational Research. https://doi.org/10.13189/ ujer.2020. 080212

Sarkadi, Syarifa, S., \& Casmana, A. R. (2020). The Policy of Education Based on Character Values for The Best Quality of Education "An Analysis of The Zoning System Policy Imposed by Ministry of Education and Culture in Indonesia." Yakugaku Zasshi. 8(8): 3423-3429, 2020 https://doi.org/ 10.13189/ujer.2020.080816

Setiawan, A. (2014). Prinsip Pendidikan Karakter Dalam Islam. Dinamika Ilmu, 14(1), 47-64. http://dx.doi.org/ 10.24014/ jdr.v27i2.2517

Setiawati, A. S. (2020). Character Value in Japanese Early Childhood Formed Through Hajimete No Osaka (First Errand). 
International Journal of Innovation, Creativity and Change. 27(2), 87-96. http://dx.doi.org/ 10.24014/jdr.v27i2.251

Setyawan, C. E., Basit, L. A., \& Fathoni, M. (2018). Telaah Bahan Ajar Bahasa Arab "Ayo Fasih Berbahasa Arab" Madrasah Aliyah Kelas Xii Karya Hasan Saefullah (Tinjauan Materi Berdasarkan Teori Mackey). Prosiding Konferensi Nasional Bahasa Arab IV.

Shen, L. (2012). Context And Text. Theory and Practice in Language Studies, 2(12), 2663-2669. https://doi.org/ 10.4304/tpls.2.12.2663-2669

Shuhari, M. H., Wok Zin, E. I. E., al-Shafi'i, M. M. deen O., Musa, R., Zin, S. A. M., \& S.H.S, O. (2019). An Ethical Aspect Of Character Building: Ibn Sina's Perspective. Journal of Legal, Ethical and Regulatory Issues.

Skierkowski, D., \& Wood, R. M. (2012). To Text or Not to Text? The Importance of Text Messaging among College-Aged Youth. Computers in Human Behavior. https://doi.org/ 10.1016/j.chb.2011.11.023

Sokip, Akhyak, Soim, Tanzeh, A., \& Kojin. (2019). Character Building in Islamic Society: A Case Study of Muslim Families in Tulungagung, East Java, Indonesia. Journal of Social Studies Education Research.

Suarmini, N. W., Rai, N. G. M., \& Marsudi, M. (2016). Karakter Anak Dalam Keluarga Sebagai Ketahanan Sosial Budaya Bangsa. Jurnal Sosial Humaniora (JSH), 9(1), 78-95.

Subianto, J. (2013). Peran Keluarga, Sekolah, Dan Masyarakat Dalam Pembentukan Karakter Berkualitas. Edukasia: Jurnal Penelitian Pendidikan Islam, 8(2).

Sujana, I. W. C. (2019). Fungsi Dan Tujuan Pendidikan Indonesia. Adi Widya: Jurnal Pendidikan Dasar. https://doi.org/ 10.25078/aw.v4i1.927

Suprayitno, E., Rois, S., \& Arifin, A. (2019). Character Value: The Neglected Hidden Curriculum in Indonesian EFL Context. Asian EFL Journal.

Suryadarma, Y., \& Haq, A. H. (2015). Pendidikan Akhlak Menurut Imam Al-Ghazali. At-Ta'dib, 10(2), 362-381. https:// ejournal.unida.gontor.ac.id/index.php/tadib/user/register

278 |VOL. 9 NO. 2 DECEMBER 2020 
Sutomo, I. (2014). Modification of Character Education into Akhlaq Education for The Global Community Life. Indonesian Journal of Islam and Muslim Societies.4(2), 291-316. https://doi.org/ 10.18326/ijims.v4i2.291-316

Suyitno, I. (2012). Pengembangan Pendidikan Karakter dan Budaya Bangsa Berwawasan Kearifan Lokal. Jurnal Pendidikan Karakter, 1 .

Syarif, H. (2016). Sistem Informasi Geografis Pondok Pesantren Berbasis Web di Wilayah Kota Bekasi (Doctoral dissertation, Universitas Bhayangkara Jakarta Raya).

Syarifah, S. (2020). Analisis Seleksi dan Gradasi Materi Buku Teks Al-Arabiyyah baina Yadaik. SUSTAINABLE: Jurnal Kajian Mutu Pendidikan. 3(1), 35-54. https://doi.org/ 10.32923/ kjmp.v3i1.1387

Tambak, S., \& Sukenti, D. (2020). Strengthening Islamic Behavior and Islamic Psychosocial in Developing Professional Madrasah Teachers. Cakrawala Pendidikan. 39(1), 6578.https://doi.org/10.21831/cp.v39i1.26001

Thompson, R. A., \& Anderson, J. A. (2019). Perception of Politeness: Some Perspectives From Ghana. Journal of Politeness Research. https://doi.org/10.1515/pr-2014-0008

Tolchah, M., \& Mu'ammar, M. A. (2019). Islamic Education in The Globalization Era; Challenges, Opportunities, and Contribution of Islamic Education in Indonesia. Humanities and Social Sciences Reviews. 7(4), 1031-1037. https://doi.org/10.18510/hssr.2019.74141

Uge, S., Neolaka, A., \& Yasin, M. (2019). Development of Social Studies Learning Model Based on Local Wisdom in Improving Students' Knowledge and Social Attitude. International Journal of Instruction. 12(3), 375-3. https://doi.org/10.29333/iji.2019.12323a

Ugurlu, N. B. (2014). Important Values of American and Turkish Students. Eurasian Journal of Educational Research. 55, 91107. https://eric.ed.gov/?id=EJ1060473

Umami, I., Gani, A., \& Waskito, T. (2019). Proposal of Character and Moral Education for Gifted Young Scientists in Indonesia. Journal for the Education of Gifted Young Scientists. 7(2), 
377-387. https://doi.org/10.17478/JEGYS.579560

Van Dijk, T. A. (2006). Discourse, Context, and Cognition. Discourse Studies. https://doi.org/10.1177/1461445606059565

Wibawa, S. (2013). "Nilai filosofi Jawa" in Litera, 12(2), 328-344. https://doi.org/10.21831/ltr.v12i02.1546

Wijaya, A., Purnomolastu, N., \& Tjahjoanggoro, A. J. (2015). Kepemimpinan Berkarakter: Untuk Para Pemimpin dan Calon Pemimpin Masa Depan Indonesia. Firstbox Media.

Wulandari, D. O., \& Hodriani, H. (2019). Peran Guru Pendidikan Kewarganegaraan dalam Mencegah Kenakalan Remaja di Sekolah. Journal of Education, Humaniora and Social Sciences (JEHSS), 1(3), 139-147. https://doi.org/ 10.34007/ jehss.v1i3.28

Yunia, S. A. P., Liyanovitasari, L., \& Saparwati, M. (2019). Hubungan Kecerdasan Emosional dengan Kenakalan Remaja pada Siswa. Jurnal Ilmu Keperawatan Jiwa. 2(1), 55-64. http://journal.ppnijateng.org/index.php/jikj/article/view/296

Yusuf, M. (2014). Pendidikan Karakter Berbasis Qurani dan Kearifan Lokal. KARSA: Journal of Social and Islamic Culture. 22(1), 52-65.

Yusuf, N. (2015). Hadis Sebagai Sumber Hukum Islam (Telaah Terhadap Penetapan Kesahihan Hadis Sebagai Sumber Hukum Menurut Syafi'iy). Potret Pemikiran, 19(1). https://doi.org/ 10.30984/pp.v19i1.714

Zamroni, M. I. (2011). Islam dan Kearifan Lokal dalam Penanggulangan Bencana di Jawa. Jurnal Penanggulangan Bencana, 2(1), 1-10. 